DOI: $10.2478 /$ lpts-2019-0009

\title{
FORMATION AND STUDY OF STATIC AND DYNAMIC CHARACTERISTICS OF ELECTRONICALLY CONTROLLED DIESEL ENGINE
}

\author{
P. Dumenko ${ }^{1}$, S. Kravchenko ${ }^{2}$, A.Prokhorenko², D. Talanin ${ }^{2}$ \\ ${ }^{1}$ DiGas Ltd. \\ 31 Talsu soseja, K-17-34, Jurmala, LV-2016, LATVIA \\ e-mail: p.dumenko@digasgroup.lv \\ ${ }^{2}$ National Technical University "Kharkiv Polytechnic Institute" \\ 2 Kyrpychova Str., Kharkiv, 61002, UKRAINE
}

\begin{abstract}
Manufacturing companies of electronic control systems of diesel engines protect access to a program operation algorithm of the regulator that makes impossible adjustments and settings of its work, for example, at reequipment or operational development of a new diesel engine. Therefore, it is important to acknowledge the solution of the scientific and technical problem of an effective and reliable system creation of electronic control of diesel fuel supply with an open program algorithm of its work. During the current research, settlement and experimental studies of a diesel engine supplied with a system of electronic control of a crankshaft rotation frequency developed by the authors show rather high adequacy in results. The dynamic mathematical model of the single-cylinder diesel engine supplied with the electronic regulator of rotation frequency has been developed and verified.
\end{abstract}

Keywords: diesel engine, electronic regulator, mathematical modelling

\section{INTRODUCTION}

At the moment, leading countries continue to improve motor vehicles in order to achieve new qualities for consumers, e.g., improved controllability, ergonomics, fuel efficiency, reduction of harmful emissions into the atmosphere, improvement safety, comfort, noise level, vibration, etc. This primarily concerns the improvement of the internal combustion engine (ICE), especially diesel engines.

It is known that the diesel engine works in the wide range of the load, highspeed and thermal modes. At the same time, reduction of harmful emissions, fuel consumption, noise and vibration of the engine are promoted by such organization of management process of this object, which provides the most high-quality transitional processes in all fields of its possible operating modes. It is indisputable that this optimization is impossible without implementation of special algorithms by electronic control systems. 
However, the cost of electronic systems of regulation remains rather high, and their service and repair demand existence of expensive and difficult equipment, as well as highly skilled personnel. Besides, manufacturing companies of such systems protect access to a program operation algorithm of regulator that makes impossible adjustments and settings of its work, for example, at re-equipment or operational development of a new diesel engine.

The scientific publications devoted to development and research of algorithms of electronic control systems of engines practically are absent, and those which are known differ in laconicism of material supply.

For example, in publications [1], [2] there is information about the practical creation of electronic control systems for diesel engines, where fuel supply is controlled not by the rail of fuel pump, but by the high-pressure bleed solenoid valve. These publications consider such themes as the design, schemes, results of experimental studies and mathematical modelling, but the description of the algorithms is not disclosed by the authors. In addition, the features of diesel locomotive operation do not allow transferring the control algorithm on engines for land transport or special equipment.

Recently there has been a set of scientific publications describing the research devoted to introduction of electronic control by the engine test bench [3], [4]. The aim of these studies is reproduction of engine transient test cycles of the engine for definition of their ecological indicators. However, here, though being novel, the problem of management is solved by absolutely other object - the loading device.

There are also publications on the development of control algorithms for individual systems of an internal combustion engine - a fuel pressure accumulator [5], an air supply system [6], an exhaust gas recirculation system [7], etc. that also do not relate directly to the regulation system of the engine high-speed mode.

The publication [8] is the most appropriate material on the formulation of the problem and the methods. Authors of the research have used a control algorithm based on the interpolation of the static characteristics of the regulator stored in the controller in tabular form. This approach has some disadvantages because such organisation of calculations introduces additional load on the central processor of the controller and leads to an increase in the intrinsic time (inertia) of the electronic regulator.

Therefore, it is important to acknowledge the solution of the scientific and technical problem on creation of an effective and reliable system of electronic control of diesel fuel supply with an open program algorithm of its work.

The aim of this article is to conduct experimental studies of a diesel engine supplied with a system of electronic control of rotation frequency of a crankshaft developed by the authors to confirm its reliable performance and efficiency.

\section{THEORETICAL PART NO.1: BASICS OF THE ALGORITHMIZATION OF THE ELECTRONIC ALL-MODE DIESEL REGULATOR}

For the synthesis of the electronic control algorithm for the rail of a highpressure fuel pump (HPFP), a scientific approach has been applied based on the 
analogy with the operation of an all-mode mechanical spring-lever speed controller of direct action. Mechanical all-mode regulators of diesel engines provide accepted (but, not always optimum) operational regulatory characteristics as well as are rather reliable units.

Let us consider operation of such a mechanical all-mode regulator with a variable tightening of a spring. Its schematic diagram is provided in Fig. 1. The structural logic diagram (Fig. 2) corresponds to this scheme, which is constructed on the basis of replacement of physical processes (linear movements of links or operating forces) with information ones. For example, movement of the coupling of a sensitive element under the influence of inertia force of the rotating mass of freights can be presented as a certain algorithm of measurement of rotation speed, and spring tightening force - as an algorithm of processing of change of the main external influence. From this point of view, the lever of the regulator can be presented as a certain calculator whose equilibrium position unambiguously defines value of an output signal of movement of a rail of HPFP, $(\mathrm{Hp})$.

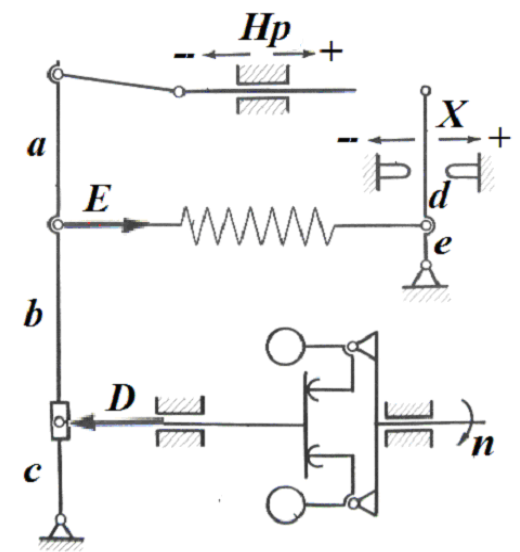

Fig. 1. The all-mode regulator with a variable tightening of a spring. Schematic diagram.

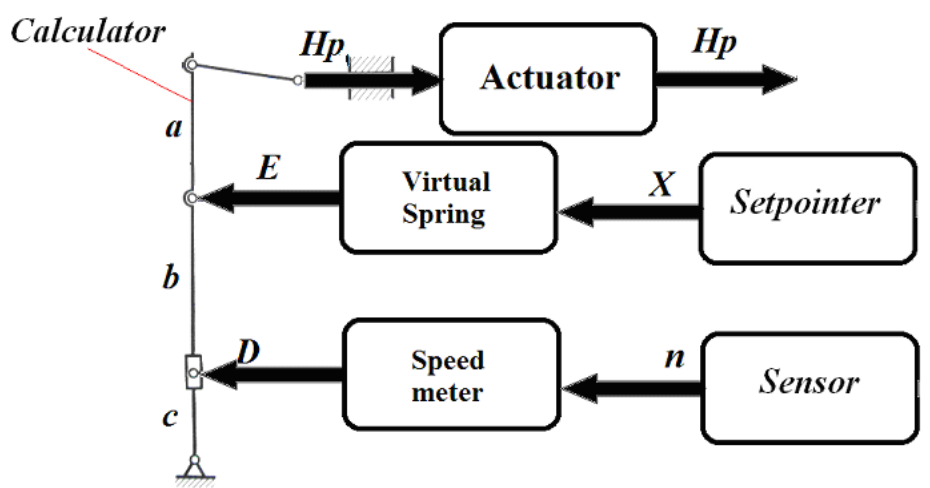

Fig. 2. Scheme of information analogy of operation of the all-mode regulator.

Then a condition of static balance of the all-mode regulator with a variable tightening of a spring is possible to describe by mathematical equality: 


$$
E \cdot(b+c)=D \cdot c
$$

Here $E$ is a conditional restoring force, which is similar to regulator spring tightening force. This force consists of force of a preliminary tightening of a spring (E0) and its current deformations brought to the lever connected with the movement of a control lever $(X)$ and a rail of $\operatorname{HPFP}(H p)$ :

$$
E=E_{0}+C \cdot \bar{X} \cdot\left(X_{\max }-X_{\min }\right) \frac{e}{d+e}-C \cdot \overline{H p} \cdot\left(H p_{\max }-H p_{\min }\right) \frac{b+c}{a+b+c}
$$

where $C$ - virtual coefficient of rigidity of a spring, N/m. With line in this formula and further relative sizes are designated.

The conditional supporting force $D=f(\omega)$ - in fact, is a measuring instrument of rotation speed. Let us assume that it complies with linear dependence. Then:

$$
D=K \cdot \bar{\omega} \cdot\left(\omega_{\max }-\omega_{\min }\right)=K \frac{\pi}{30} \bar{n} \cdot\left(n_{\max }-n_{\min }\right) \cdot
$$

In this formula, the constant coefficient of proportionality $K$ conditionally has dimension of Ns (an analogue of inertial coefficient of the mechanical regulator).

After substitution of expressions (2) and (3) in the initial equation (1) and their simple transformation it is possible to come to the general equation:

$$
\begin{gathered}
\frac{E_{0}}{C\left(H p_{\max }-H p_{\min }\right)} \cdot \frac{a+b+c}{b+c}+\frac{X_{\max }-X_{\min }}{H p_{\max }-H p_{\min }} \cdot \frac{e(a+b+c)}{(d+e)(b+c)} \cdot \bar{X}-\overline{H p}= \\
=\frac{\pi}{30} \cdot \frac{K\left(n_{\max }-n_{\min }\right)}{C\left(H p_{\max }-H p_{\min }\right)} \cdot \frac{c(a+b+c)}{(b+c)^{2}} \bar{n} .
\end{gathered}
$$

It is visible that in this equation there are constants, which we will designate as follows:

$$
\begin{gathered}
A_{1}=\frac{E_{0}}{C\left(H p_{\max }-H p_{\min }\right)} \cdot \frac{a+b+c}{b+c}, \quad A=\frac{X_{\max }-X_{\min }}{H p_{\max }-H p_{\min }} \cdot \frac{e(a+b+c)}{(d+e)(b+c)}, \\
B=\frac{\pi}{30} \frac{K\left(n_{\max }-n_{\min }\right)}{C\left(H p_{\max }-H p_{\min }\right)} \cdot \frac{c(a+b+c)}{(b+c)^{2}} .
\end{gathered}
$$

Then we have record of equation (1):

$$
\overline{H p}=A_{1}+A \cdot \bar{X}-B \cdot \bar{n}
$$

The received equation (4) is a required algorithm of the electronic regulator operation. Using it is possible to calculate static characteristics of the regulator in the form of dependence $\overline{H p}=f(\bar{X}, \bar{n})$, and selection of values of coefficients of $A_{1}, A$ 
and $B$ - set their required look. The following values of coefficients were accepted: $A_{1}=0.58, A=1.22$ and $B=1$.

\section{EXPERIMENTAL PART NO. 1: IMPLEMENTATION OF A CONTROL SYSTEM AT THE RESEARCH MOTOR BENCH}

To check the operability of the described operation algorithm of the electronic regulator of a crankshaft rotation frequency, engine testing studies were performed. The engine (the cylinder sizes: diameter of $120 \mathrm{~mm}$, a piston stroke of $140 \mathrm{~mm}$ ) was used, which was mounted on the laboratory test bench. This engine was the singlecylinder diesel with power up to $30 \mathrm{~kW}$ with a crankshaft rotation frequency from 700 to $1400 \mathrm{~min}^{-1}$. Diesel engine test bench differed in the following design features:

- Injection of fuel in a cylinder was carried out by the high pressure fuel feeding system with the individual fuel pump (Unit Pump System).

- The engine lubrication system was autonomous.

- The cooling system - liquid, autonomous, with separate streams of cooling liquid in the block and a head of a cylinder.

- Engine start was carried out by means of the electric load device, which was part of the test bench.

- The engine had the mechanism of equilibration of inertia forces like Lanchester.

- In a head of a cylinder, the gas channel for installation of the indication sensor was implemented.

Besides, the test bench was equipped with all necessary devices and sensors for carrying out measurements of the current operation parameters of the engine.

The function chart of the developed electronic system of automatic control (SAC) of the diesel is shown in Fig. 3. As it is seen from the drawing, external and internal influences of such SAC are: $X(t)$ - the current position of governing body of the engine, $n(t)$ - the current rotation frequency of a crankshaft of the engine, $H p$ - position of governing body of fuel feeding (rail of HPFP), $B c$ - cyclic supply of fuel by HPFP and $M c(t)$ - the loading resistance moment. The letter $t$ designates the current time.

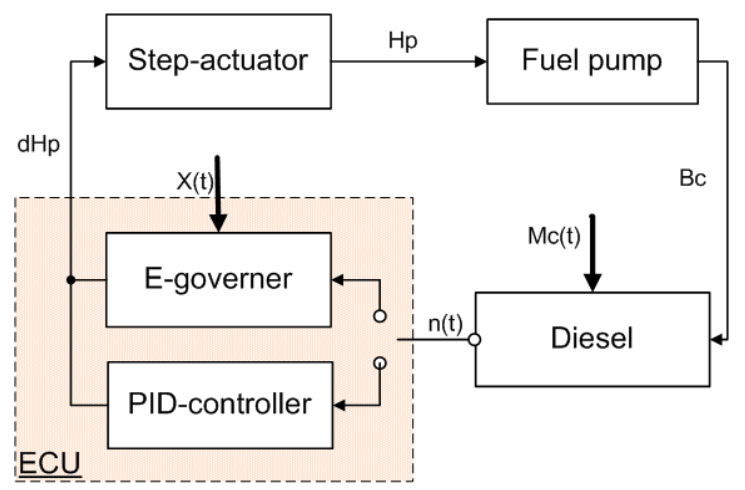

Fig. 3. Function chart of the electronic regulator of crankshaft rotation frequency. 
The main components of the developed system of the electronic regulator are: ECU on ATmega328 microcontroller; actuator; position sensors of a pedal of an accelerator, the «Start» and «Auto» buttons intended for initialization, according to the engine starting modes and PID regulation. Step actuator developed by company «DigasGroup» (Latvia) was used as the actuator for the drive of a rail of the fuel pump.

The accelerator pedal sensor was intended for registration of movement of a control lever and transmitted the corresponding signal to ECU.

Crankshaft rotation frequency was calculated by time of the period of signal of the inductive sensor installed opposite to a flywheel on which the magnetic plate was located.

The microcontroller processed primary received information from sensors, the "Start" and "Auto" buttons and implemented the program control algorithm put in it. By processing results of these signals, the microcontroller reacted via the actuator. Contact of the microcontroller with the actuator was implemented through the protocol of data transmission MAX-485.

ECU had the converter of interfaces USB-UART through which connection to the personal computer for its programming was carried out.

As the interface, 16 symbolical liquid crystal indicator was used on which the current information was transmitted: relative provision of a rail of the fuel pump and control lever, operating mode of the regulator, etc. Electronic regulator does not demand change of a design of the fuel pump; it is flexible and universal in regulation, can be installed on various types of diesel engines.

\section{EXPERIMENTAL PART NO. 2: STATIC AND DYNAMIC CHARACTERISTICS OF THE DIESEL}

The performed motor tests of a control system on the studied diesel showed that at introduction of electronic regulation on the equilibrium modes stability of crankshaft rotation frequency considerably increased (to $\Delta \mathrm{n}= \pm 2 \mathrm{~min}^{-1}$ ) irrespective of fuel quality, technical condition of the engine, environmental conditions and other external factors.

The program of the performed tests in the form of a set of pairs of setting regime parameters was the following: "relative position of governing body of X Mc loading resistance moment size" and the measured indicators corresponding to them: crankshaft rotation frequencies $n$, the current relative provision of a rail of HPFP $\mathrm{Hp}$ and mass hour fuel consumption.

The results received during tests allowed:

1. Experimentally confirming a type of static characteristic of the electronic regulator.

2. Defining and visualising regulatory characteristics of the diesel (provided in Fig. 4) - dependence of value of relative effective torque $\overline{M e}$ of the crankshaft rotation frequency $n$ at various constant provisions of governing body of $\mathrm{X}$. 


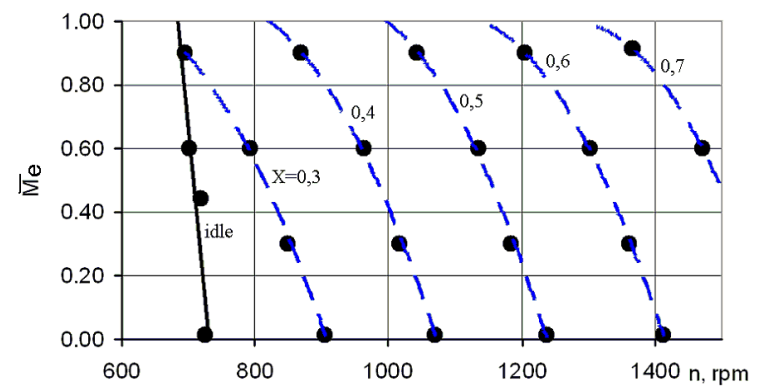

Fig. 4. Regulatory characteristics of the diesel engine.

3. Defining and visualising static characteristic of HPFP of the studied diesel engine (provided in Fig. 5) - dependence of relative value of its volume cyclic supply of fuel on the rotation frequency of crankshaft $n$ at various constant provisions of governing body of X.

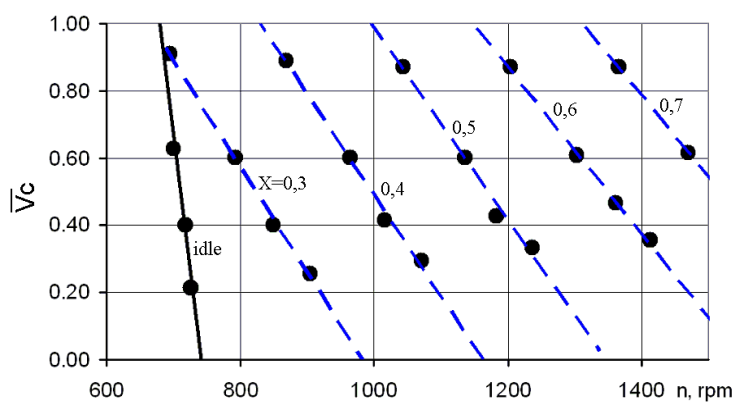

Fig. 5. Static characteristic of HPFP with the regulator.

4. Synthesising a basic matrix of fuel feeding of $B c=f(n, X)$ for the current diesel necessary for creation of more complex system of management on the basis of predictive model (Model Predictive Control). This matrix was received by the method of interpolation-extrapolation of data in 22 separate experimental points. Graphically this matrix is presented in the surface form in Fig. 6. In the same place, values of the experimental data forming a basis for synthesis of the table are shown.

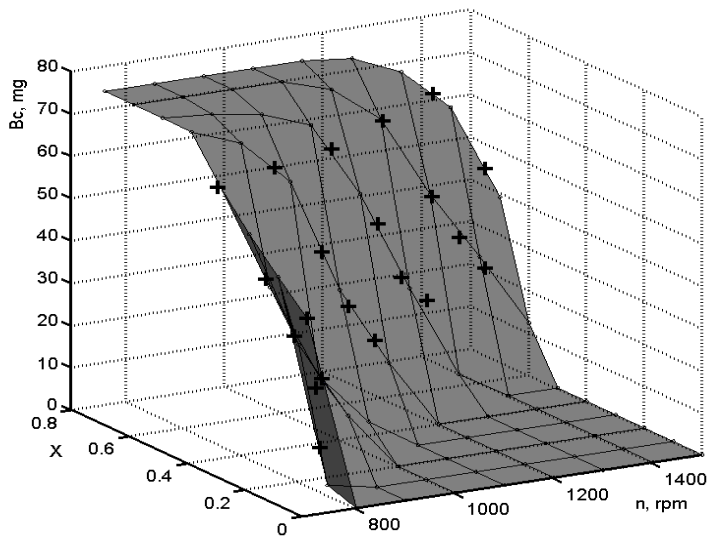

Fig. 6. The synthesized basic table of fuel feeding with experimental points (+). 
Apparently from the provided drawings, the results received during the experiment did not contradict the standard requirements of regulation systems of diesel engines of different functions, especially in transport. Besides, the carried tests of the engine showed that the use of the offered electronic regulator allowed reducing time of transition processes between the required set modes.

For development and verification of a dynamic mathematical model of the studied diesel control system, records of a temporary track of the crankshaft current speed were received at the determined change of position of governing body of the engine. Example is given in Fig. 7.
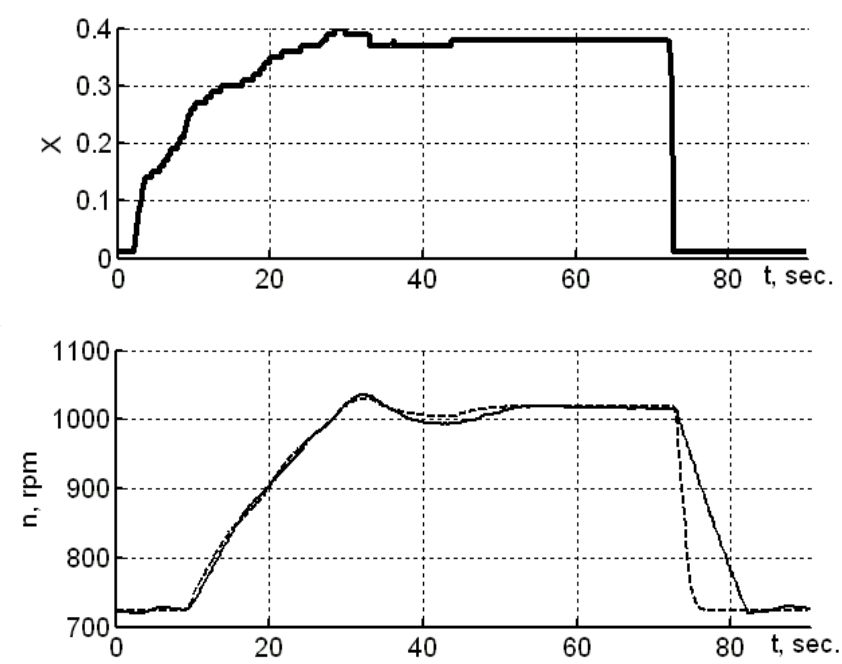

Fig. 7. Dynamic characteristics and results of mathematical modelling of an electronic system of regulation: ---- calculation; _- experiment.

\section{THEORETICAL PART NO. 2: DESCRIPTION AND VERIFICATION OF MATHEMATICAL MODEL OF DYNAMICS OF A CONTROL SYSTEM}

The calculation scheme of mathematical model of the developed electronic control system is provided in Fig. 8. In the form of internal information communication, the following sizes used as system coordinates are designated: $\Delta H p$ - the rejection of the provision of a rail of HPFP demanded for achievement of the equilibrium mode; $\Delta H p^{\prime}$ - the valid deviation of a rail of HPFP from equilibrium situation; $\Delta \omega$ - the current deviation from equilibrium value of angular speed of a crankshaft; $\omega_{0}$ - a value of angular speed of the set equilibrium mode; $n-$ an absolute value of rotation frequency of the engine; $X$ - position of governing body of the engine.

For the description of the movement of a crankshaft of the engine, we use the known differential equation

$$
J \frac{d \omega}{d t}=M e-M c
$$




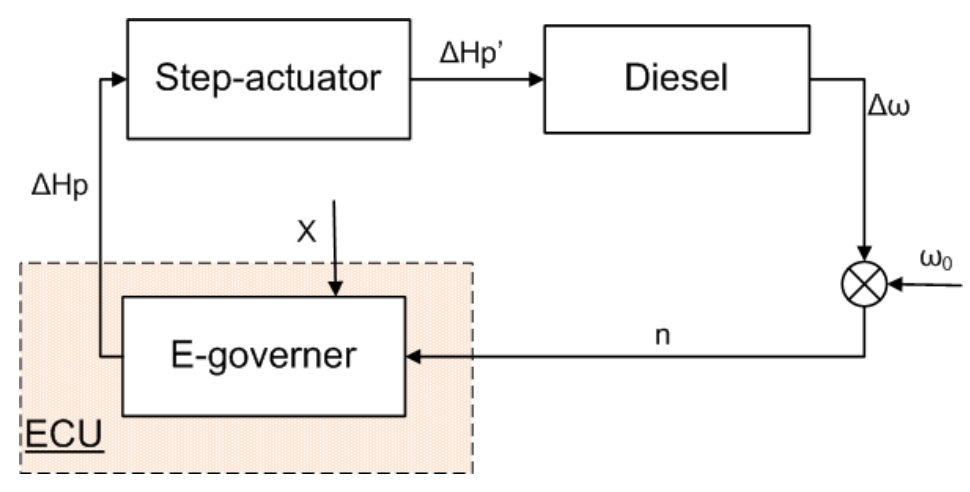

Fig. 8. Calculation scheme of mathematical model.

Assuming that the effective torque of the engine $M e$ is linearly proportional to the size of cyclic supply of fuel $B c$ (that is fair for naturally aspirated engine), which unambiguously is determined by the current valid position of a rail of HPFP $H p^{\prime}$.

$$
M e=f(B c)=f\left(H p^{\prime}\right)=A_{A} \cdot H p^{\prime} .
$$

We also consider that the loading resistance moment $M_{C}$ linearly depends on the angular crankshaft rotation speed.

$$
M c=f(\omega)=B_{B} \cdot \omega .
$$

Here $A_{A}, B_{B}$ - constant coefficients of proportionality.

Equation (5), taking into account a small deviation from the equilibrium mode $\Delta$, is as follows:

$$
J \frac{d\left(\omega_{0}+\Delta \omega\right)}{d t}=A_{A} \cdot\left(H p_{0}^{\prime}+\Delta H p^{\prime}\right)-B_{B} \cdot\left(\omega_{0}+\Delta \omega\right)
$$

Considering a preliminary condition of the steady, equilibrium mode $\operatorname{Me}\left(H p_{0}^{\prime}\right)=\operatorname{Mc}\left(\omega_{0}\right)$, and zero derivative of constants, it could be simplified and given to the normalized look:

$$
J \frac{d \Delta \omega}{d t}=A_{A} \cdot \Delta H p^{\prime}-B_{B} \cdot \Delta \omega
$$

The received equation (6) was the main settlement equation of mathematical model. Its numerical decision relatively $\Delta \omega$ allowed defining the current deviation of rotation frequency from its equilibrium value $n_{0}$ :

$$
\Delta n=9.549 \cdot \Delta \omega
$$


Then the absolute value of the current frequency of rotation would be $n=n_{0}+\Delta n$.

The required value of equilibrium provision of a rail of HPFP (mathematical description of work of an algorithm of ECU) for the current cycle was calculated by formula (4) taking into account that $H p=H p_{0}+\Delta H p$, where $\Delta H p=A_{1}+A \cdot X-B \cdot n-H p_{0}$.

Writing up the differential equation of the movement of a rail of HPFP, it was accepted that it was without inertial part, but its movement was implemented to constant relative linear speed $C=\frac{d \Delta H p^{\prime}}{d t}=0.0415 \mathrm{~s}^{-1}$. At the same time, its movement continuously continued before achievement of the set equilibrium situation $H p=H p_{0}+\Delta H p$ and takes time $\Delta t_{K}=\frac{\Delta H p}{C}$. Therefore, change in the valid rejection of the position of a rail of HPFP in time could be described by the integrated equation $\Delta H p^{\prime}=C \int_{t_{0}}^{t_{0}+\frac{\Delta H p}{C}} d t$.

The general algorithm of creation of calculations for the described mathematical model has the following sequence.

1. The current time interval for numerical integration on i-th step:

$$
\Delta t_{i}=120 / n_{i-1} \text {. }
$$

2. The current required rejection of the provision of a rail of HPFP for achievement of the equilibrium mode:

$$
\Delta H p_{i}=A_{1}+A \cdot X_{i}-B \cdot n_{i-1}-H p_{0} .
$$

3. The current valid rejection of the provision of a rail of HPFP in each timepoint $t_{i}=t_{i-1}+\Delta t_{i \text { till moment }} t_{K}=t_{0}+\Delta t_{K}$ :

$$
\Delta H p_{i}^{\prime}=C\left(t_{i}-t_{0}\right) \text {. }
$$

4. Current deviation of crankshaft angular speed:

$$
\Delta \omega_{i}=\frac{1}{J}\left(A_{A} \cdot \Delta H p_{i}^{\prime}-B_{B} \cdot \Delta \omega_{i-1}\right) \Delta t_{i}+\Delta \omega_{i-1} .
$$

5. Current value of rotation frequency of the engine:

$$
n_{i}=n_{0}+\frac{30}{\pi} \Delta \omega_{i}
$$

After verification of the mathematical model consisting in selection of values of the mass moment of inertia of mobile parts of engine $J$ and coefficients of proportionality $A_{A}, B_{B}$ in equation (6), comparative calculation was carried out for the received experimentally temporary track of the current speed of a crankshaft $n(t)$ at the determined change of position of governing body of the engine $X(t)$. Its results are shown in the experimental graph (Fig. 7). At the same time, values $J=30 \mathrm{~kg} \times \mathrm{m}^{2}$ were accepted (used single-cylinder engine had a massive flywheel), $A_{A}=1375 \mathrm{Nm}, B_{B}=0.05 \mathrm{Nm}$.

As it is seen from the drawing, the model rather adequately repeats an experimental track that validates the developed calculation procedure and allows using this mathematical model as a tool for carrying out further settlement studies. 


\section{CONCLUSIONS}

As a result of the present research the following main results have been received:

1. Theoretical justification of synthesis of a program operation algorithm of the electronic regulator of diesel engine rotation frequency has been made.

2. The system of electronic all-mode regulation of crankshaft rotation frequency of the diesel engine has been developed and implemented on the motor research bench.

3. The operability of the developed electronic regulation system has been completely confirmed by studies of additional device. During tests, static and dynamic characteristics of this system have been received.

4. The dynamic mathematical model of the studied single-cylinder diesel engine supplied with the electronic regulator of rotation frequency has been developed and verified. Results of calculation with the use of this mathematical model have shown its rather high adequacy.

5. For the studied diesel, the basic matrix of fuel feeding $B c=f(n, X)$ has been synthesized, necessary for creation of a control system on the basis of predictive model.

\section{ACKNOWLEDGEMENTS}

This project has received funding from the European Union's Horizon 2020 research and innovation programme under grant agreement No 784620.

\section{REFERENCES}

1. Furman, V.V., Ivanov V.A., \& Markov, V.A. (2013). Electronic control systems for diesel engines. Science and Innovations, 5, 1-18. (in Russian)

2. Bogaevsky, A.B. (2001). Microprocessor system for control of rotation frequency and power of diesel-generator installation. HGADTU Bulletin, Kharkiv, 15-16, 153-156. (in Russian)

3. Lopez, J., Espinosa, O.J., \& Agudelo, J. (2011). LQR control for speed and torque of internal combustion engines. In 8th IFAC World Congress (pp. 2230-2235), 28 August-2 September, 2011, Milano. 10.3182/20110828-6-IT-1002.02176.

4. Payo, I., Sánchez, L., Caño, E., \& Armas, O. (2017). Control applied to a reciprocating internal combustion engine test bench under transient operation: Impact on engine performance and pollutant emissions. Energies, 10, 1690.

5. Lu, Y., Zhao, C., Zuo, Z., Zhang, F., \& Zhang, S. (2017). Research on the common rail pressure overshoot of opposed-piston two-stroke diesel engines. Energies, 10, 571.

6. Simani, S., \& Bonfè, M. (2009). Fuzzy modelling and control of the air system of a diesel engine. Advances in Fuzzy Systems, Article ID 450259, 14. DOI:10.1155/2009/450259

7. Dong, T., Zhang, F., Liu, B., \& An, X. (2015). Model-based state feedback controller design for a turbocharged diesel engine with an EGR system. Energies, 8, 5018-5039.

8. Golovchuk, A.F. (2014). Universal electronic regulator for tractor diesel. Internal Combustion Engines, 1, 31-34. (in Ukrainian) 


\title{
ELEKTRONISKI VADĀMA DĪZELLMOTORA STATISKO UN DINAMISKO RAKSTURLĪKN̦U IZVEIDE UN IZPĒTE
}

\author{
P. Dumenko, S. Kravčenko, A. Prokhorenko, D. Talanin
}

Kopsavilkums

Dīzeḷmotoru elektronisko vadības sistēmu ražojošās kompānijas aizsargā piekḷuvi regulatoru algoritmu darbības programmām, kas padara praktiski neiespējamu to darbības korekciju un iestatījumu mainu, piemēram, jauna dīzel̦motora pārbūves vai uzlabošanas gadījumos. Tāpēc ir svarīgi atzīmēt zinātniski-tehniskos šādu problēmu risinājumus, kas saistīti ar efektīvu un uzticamu sistēmu izveidi dīzeḷdegvielas padeves sistēmas kontrolei ar atvērtās darba programmas algoritmu. Teorētiskajos un eksperimentālajos pētījumos par autoru izveidoto dīzeḷmotora kloḳvārpstas apgriezienu elektroniskās kontroles sistēmu tika konstatēta iegūto rezultātu zināma līdzība. Pêtījumu gaitā tika izveidots un verificēts izpētes viencilindra dīzeḷmotora, aprīkota ar elektronisko apgriezienu regulatoru, dinamiskais matemātiskais modelis.

09.01.2019. 